Article

\title{
Indicators of Socio-Spatial Transport Disadvantage for Inter-Island Transport Planning in Rural Philippine Communities
}

\author{
David Cao ${ }^{1, *}$, John Stanley ${ }^{2}$ and Janet Stanley ${ }^{3}$ \\ ${ }^{1}$ Transport for New South Wales, NSW 2008, Australia; E-Mail: david.cao@transport.nsw.gov.au \\ 2 Institute of Transport and Logistics Studies, Business School, University of Sydney, NSW 2006, Australia; \\ E-Mail: john.stanley@sydney.edu.au \\ ${ }^{3}$ Melbourne Sustainable Society Institute, Melbourne School of Design, University of Melbourne, Victoria 3010, Australia; \\ E-Mail: janet.stanley@unimelb.edu.au \\ * Corresponding author
}

Submitted: 9 July 2017 | Accepted: 22 September 2017 | Published: 28 December 2017

\begin{abstract}
This article seeks to identify areas of relative transport disadvantage within an archipelagic region of the Philippines, so its people can be privileged through the provision of faster inter-island journeys to support social inclusion. It assesses the constraints that limit travel between cities and townships by undertaking a small travel behavior survey and trip generation/distribution model across four population centres, to observe how physical isolation from larger centres of social confluence can be reflected by lower trip volumes and associated increases in risks of social exclusion. The article's methodology makes use of limited information to identify where reductions in inter-island travel time can be proposed for people living in areas of greater relative transport, social and economic disadvantage, so that individual economic and personal travel opportunities can be made more accessible, reducing exclusion risks and promoting well-being.
\end{abstract}

\section{Keywords}

intermodal transport; island; mobility; Philippines; regional development; social exclusion; transport disadvantage

\section{Issue}

This article is part of the issue "Regional and Urban Mobility: Contribution to Social Inclusion", edited by Janet Stanley (University of Melbourne, Australia) and John Stanley (University of Sydney, Australia).

(C) 2017 by the authors; licensee Cogitatio (Lisbon, Portugal). This article is licensed under a Creative Commons Attribution 4.0 International License (CC BY).

\section{Introduction}

Mobility is often difficult in rural areas and archipelagic settings, where geographical isolation from major population centres is linked to poor accessibility and lost opportunities for inclusion and human development. Understanding transport systems across all modes, and associated constraints, precedes an appropriate institutional response in such places.

The Philippines is a South East Asian nation comprising 7,641 islands that support a population of over 100 million people. This creates mobility and access issues for a country challenged by its archipelagic dispersion of islands, expanding population and rapid urbanization. This article focuses on one of the seventeen administrative regions of the Philippines, MIMAROPA (see Figure 1), which comprises 1,978 islands, $29,621 \mathrm{~km} 2$ of land, and is home to approximately three million people (Philippine Statistics Authority, 2017).

The article seeks to understand the problem of social exclusion associated with limited inter-island transport connections in MIMAROPA and to identify some opportunities to reduce exclusion risks and promote greater social equality. It assesses constraints that limit travel between islands, by undertaking a small travel behavior survey and trip generation/distribution model across four of the region's population centres. The observations illustrate how physical isolation from larger centres of so- 


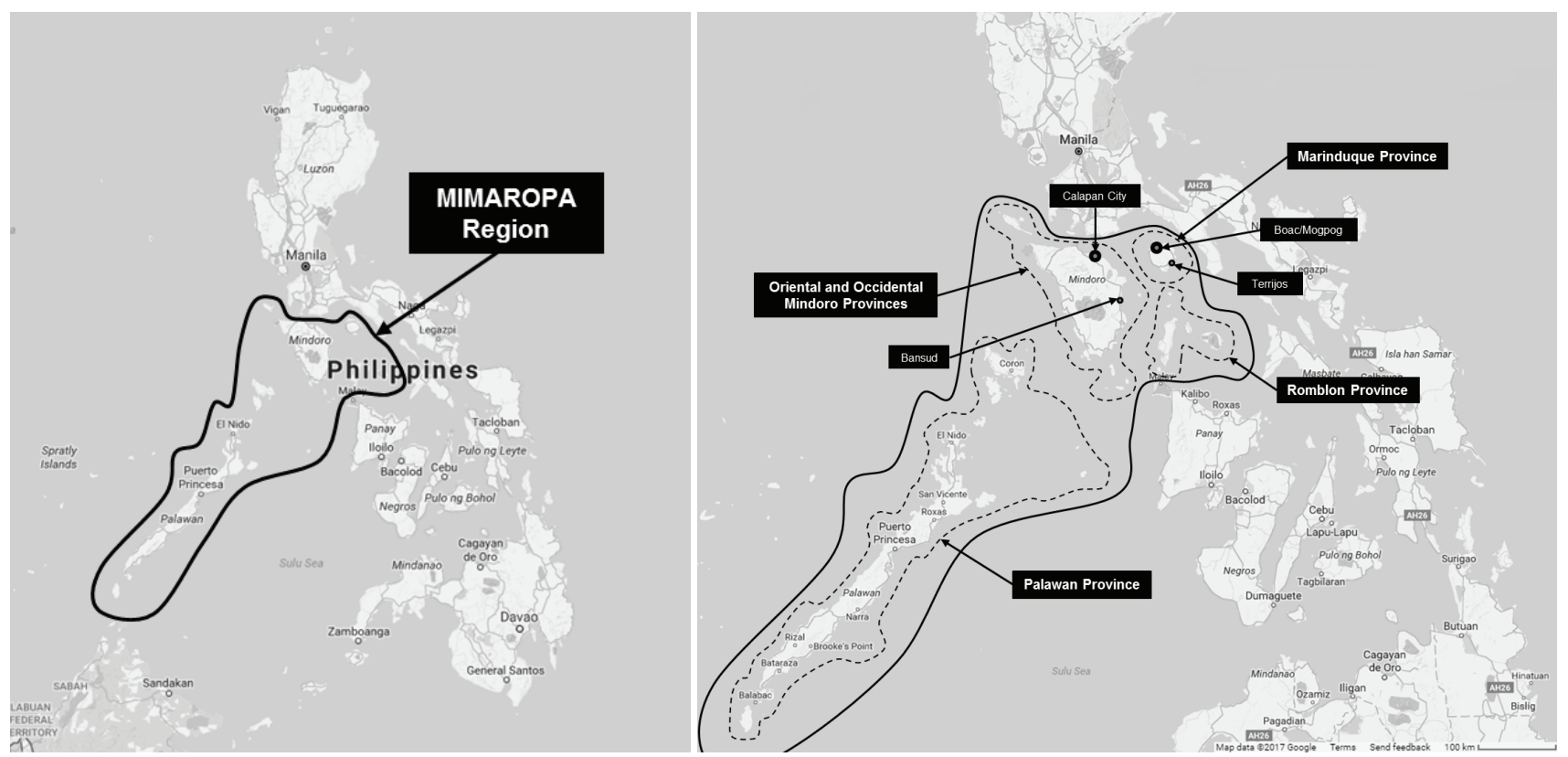

Figure 1. Map of the Philippines, MIMAROPA and its provinces within the Philippine Islands.

cial confluence can be reflected by lower trip volumes, which has implications for individual economic opportunity and social inclusion. Inter-modal network and infrastructure changes are proposed for MIMOROPA, with a view to improving mobility opportunities for people from areas of greater relative transport, social and economic disadvantage.

The article is organized as follows: Section 2 summarizes key literature relevant to the subject matter, focusing particularly on transport/mobility and social inclusion in a rural/regional setting; Section 3 provides background information on the study area; Section 4 sets out the findings from a survey undertaken for the study, to shed light on whether rural/regional people are likely to be at risk of social exclusion for reasons of lack of transport opportunities; Section 5 presents the results; and Section 6 includes some discussion and sets out the article's conclusions.

\section{Literature Review}

The contemporary literature on social exclusion has a strong focus on developed economies, such as the European Union and Australia, where large-scale social environments have been built around the assumption of high mobility. Levitas et al. $(2007$, p. 9) define social exclusion as:

The lack or denial of resources, rights, goods and services, and the inability to participate in the normal relationships and activities available to the majority of people in a society, whether in economic, social, cultural or political arenas. It affects both the quality of life of individuals and the equity and cohesion of society as a whole.
Social exclusion thus implies that an individual is not able to participate in the mainstream society in which he or she lives (Piachaudt, LeGrand, \& Piachaud, 2002), and some groups are particularly subject to social exclusion risks, such as children and youth, elderly people, those with a disability, those on low incomes, and those who live in rural or isolated areas (Stanley, Hensher, Stanley, \& Vella-Brodrick, 2011).

Social exclusion is often linked to the role of transport in providing individuals with access to increased opportunities for social interaction (Stanley, Stanley, \& Davis, 2014). The link between social exclusion and transport is mediated through development of a form of social capital known as bridging social capital (Vella-Brodrick \& Stanley, 2013). Different networks of connected people create different types of social capital (Stone, Gray, \& Hughes, 2003). Bonding social capital assists the process of 'getting by' on a daily basis. The networks are close and dense and foster trust and reciprocity. Bridging social capital allows people to 'get ahead' by accessing multiple networks and therefore resources and opportunities, thus increasing social inclusion. For remote island communities dependent on inter-island transport, access to a broader range of social and economic opportunities is likely to be impeded by expensive, infrequent and unreliable transport.

The concept of social exclusion has not been adopted in developing countries until comparatively recently. The World Bank published what would appear to be its first report on social inclusion in developing countries in 2013, but it does not refer to the association between transport and social inclusion. Social exclusion is mentioned in five of the United Nations' 17 Sustainable Development Goals (United Nations, 2017). Sustainable Development Goal 11 , urban sustainable development, includes an important sub-section on transport and refers to vulnerability: 
11.2-By 2030, provide access to safe, affordable, accessible and sustainable transport systems for all people and goods, improving road safety and expanding public and non-motorized transport, with attention to the needs of those in vulnerable situations. (Simon \& Arfvidsson, 2015, p. 6)

The Sustainable Development Goals are becoming increasingly important in defining global policy and priorities, becoming the main criteria in 2015 for setting geographical priorities in decentralized development cooperation, that is, cooperation between international cities and regions (Marta \& Akhmouch, 2017). Thus, understanding the role of transport and its impact on social inclusion is of considerable importance to the Philippines, given the disparities in social equity between its cities and regions (see Section 3 below). Understanding disaggregated sub-national metrics that reveal regional disparities is said to be important in understanding a country's achievement of goals, despite possible challenges in gathering this data in developing countries.

Social exclusion is commonly concentrated in fringe and peri-urban areas in both developed and developing cities (UN-Habitat, 2013). Similarly, rural and regional areas commonly have higher levels of social exclusion and accessibility barriers, where people have difficulty reaching services to meet their essential needs due to poorly developed public transport systems.

Social exclusion needs to be understood within a cultural, political and spatial context. In a developed country, social exclusion is understood as an inability to have the opportunities to take part in the dominant societal structures/economic paradigm, in terms of employment, service availability and participation. This paradigm is commonly being replicated in developing countries where a form of market-based capitalized economy is seen as the solution to removing poverty. However, inclusion and well-being could also be viewed in the context of a more traditional economy, based on a village setting.

The work of Sen in the late 1990s holds particular relevance for Philippine rural development. Sen (1999) proposed that development should be evaluated in terms of 'the expansion of capabilities,' so that people can lead the kind of lives they value and have reason to value. Moreover, he indicates that social exclusion is a complex matter and encompasses a range of dimensions that go beyond poverty. For example, the full promotion of human rights and political liberty is central to the contemporary political rhetoric, and the notion of 'development as freedom' characterizes much of the prevailing democratic aspiration.

Transport services are essential in helping people reach destinations they deem important and the transport system is, at its core, invested in enabling individual capacity (Cass, Shove, \& Urry, 2005). Mobility is both a direct driver of social inclusion, in that it enables a person to access services and work, as well as being a facilitator of other drivers, enabling people to build social capital and connection to community (Stanley, Stanley, \& Hensher, 2012). However, in a developing world, the cultural context for inclusion may well be localized, with paid employment not needed for inclusion, but rather accessibility to health (including quality food and water), and education as the major needed services. Connection to the community and social capital may be able to be achieved through informal and active transport (walking) in a rural village context. The adoption of informal and intermediate means of transport in areas devoid of formal transport supply may be important forms of meeting longer distance mobility needs to support inclusion (Cervero \& Golub, 2007). The provision of mobility may also rapidly change with the advance of new technologies, such as low-cost air carriers and faster ferries (Cass et al., 2005; Church, Frost, \& Sullivan, 2000).

Connections to bridging social capital and wider social opportunities may be spatially constrained. In an archipelagic setting like the Philippines, where interisland ferries and connecting transport are important for remote social inclusion and economic participation, it is critical that such transport is made safe, accessible and time efficient, in order to provide basic services, such as health and education, to rural and remote communities. It is the linking of smaller communities to larger regional cities that is particularly addressed in this article.

In terms of literature related to inter-island connectivity in the Philippine archipelago, development constraints imposed by the infrastructure base have been recognized by authors such as the Asian Development Bank (2010), Llanto (2016) and Francisco (2017). Llanto (2016), for example, explains how inter-island connectivity depends on a network of small municipal ports, old domestic ships and the roll-on/roll-off (RoRo) ferry system, with shipping accounting for over $80 \%$ of passenger and freight movements in this market segment. Llanto (2016, p. 243) argues that 'stronger external and interisland connectivity will enable it [the Philippines] to take advantage of trade, investment, and growth opportunities in this dynamic region, thereby fostering inclusive growth', but points out that improvement in these areas faces funding challenges.

Francisco (2017) analyses the effectiveness of the RoRo system, pointing to increases in both agricultural and non-agricultural incomes of households near RoRo ports and in agricultural incomes on nearby islands. Improved school attendance was also identified, household gains from the RoRo system being transferred to their offspring in a process that increases human capital levels. The analysis underlines the importance of the interisland transport system and, by implication, the potential opportunity for increased social inclusion associated therewith, through improved educational participation and increased household incomes, in both agricultural and other pursuits.

More broadly, however, Roxas and Fillone (2016) note the lack of transportation studies for secondary 
cities and peripheral regions in the Philippines. Their research focuses on travel time valuation for interisland passenger transport in the Western Visayas region, where they find that lower income persons have lower travel time values than those with higher incomes. As expected, therefore, lower income people are more likely to use cheaper, but relatively slower, inter-island transport modes, suggesting RoRo rather than fast ferries, or airplanes where all three are available. This is relevant for the sampling process used in this study.

\section{The Philippines and MIMAROPA Region Study Area}

Across the Philippines, expensive, infrequent and unreliable transport in remote and rural areas is shown to reduce a person's capacity to access essential healthcare, education and employment opportunities, thereby limiting full development of their human potential (National Economic and Development Authority [NEDA], 2016). In 2016, the Philippine Institute for Development Studies (2016) found that poor and low income families are highly concentrated in rural areas, with the majority of wealthy families living in urbanized areas. Additionally, the United Nations Development Programme (2013) found that development between urbanized and rural areas in the Philippines remained uneven, calling for the Philippine government to do more on inequality reduction efforts in distant and marginalized areas. Reductions to social inequality remain an important development objective of the Philippine government, as reflected in its 2017-2022 Philippine Development Plan (NEDA, 2016).

MIMAROPA's poverty incidence among families, described as the proportion of Filipino people that live below the poverty line, was estimated at $17.4 \%$ in 2015 , slightly above the national average estimate of $16.5 \%$ (PSA, 2017). By contrast, the National Capital Region, which contains the Metro Manila megacity, was estimated at only $2.7 \%$ and the adjoining, highly-urbanized CALABARZON Region at $6.7 \%$. The above average poverty incidence in MIMAROPA suggests that social exclusion is likely to be a concern and that bridging social capital should be a particularly important objective, making it a suitable study area.

In 2013, the MIMAROPA branch of the NEDA developed the MIMAROPA Intermodal Transport Plan (MITP). It informed MIMAROPA's Regional Development Plan (RDP) of 2011-2016, which identified the acceleration of socially inclusive transport infrastructure as part of its agenda (NEDA, 2014). More specifically, it sought to integrate MIMAROPA's agriculture and tourism sectors with the wider Philippine economy, expand the transport network to increase the inter-connectedness between MIMAROPA's five island provinces, position MIMAROPA's administrative centre, Calapan City, as the central node for the region's transport network and, last, to improve social equity through the prioritization of infrastructure in areas of comparatively poor access to jobs, services and people. This last objective is the primary focus of this article, particularly in terms of promoting social inclusion and improving the well-being of remote communities.

The small study is limited to passenger-based transport with a trip distance range of 0 to 300 kilometres and a focus on intermodal transport (RoRo and buses/vans). Previous work on disadvantage and transport in the MIMAROPA Region was produced by NEDA between 2011 and 2014, as part of an evidence-building exercise to inform MIMAROPA's MITP and RDP (NEDA, 2014). It acknowledged at the time that MIMAROPA's transport network lacked a fully organized system that linked its island provinces directly to one another:

Traditionally, the region has relied on private sector efforts to operate transport services. However, transport service providers thrive in the high-risk environment through the trial-and-error of routes, some with non-regular schedules, or 'special trips.' Moreover, it operates within poorly developed infrastructure assets that are poorly constructed, situated, and designed. (NEDA, 2014, p. 81)

That work developed 28 indicators of transport disadvantage in MIMAROPA, measuring traditional indicators such as travel time and journey reliability, through a survey distributed to 220 respondents across the region's five provinces. This produced a baseline understanding of MIMAROPA's transport system from the perspective of key stakeholders, which included land-transport operators, traffic managers, urban planners, academics, consultants, infrastructure advisors, private-sector investors, airport managers, tourism officers, maritime shipping operators and members of the Philippine coast guard.

The development of a polycentric transport network is central to this study's methodology of generating data (see Figures 2 and 3). A polycentric network refers to a network of communities, municipalities, regions or nations that join together for a shared or common goal. The networks can be driven by social, political, or industrial needs at local to global scales (Kramar \& Kadi, 2013). The established movement corridors serving MIMAROPA's five island provinces operate as part of a broader hub-and-spoke network, where services centralize and gravitate towards the National Capital Region, containing Metro Manila. In Figure 2, the National Capital Region can be denoted as ' $S$ ' and MIMAROPA's five provinces as ' $A$ ' through to ' $E$ '. ' $F$ ' through to ' $H$ ' can be referred to as other regions. The RDP recognizes that this network type lacks direct services between neighbouring provinces, forcing intermodal transfers between indirect nodes where people do not necessarily need to be. Thus, the RDP's response is to develop a polycentric transport network where direct 'port-to-port' services between provinces are prioritized, to lower inter-island travel times. The RDP's preferred network type is conceptualized in Figure 3. It promotes a regional polycentric hub-and-spoke system, where rural cities have increasing degrees of interconnection within their own region. 


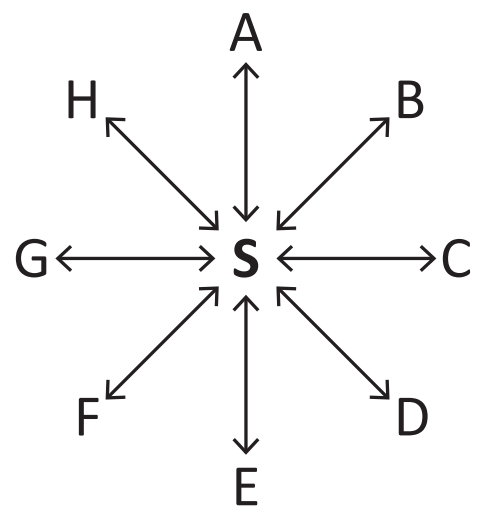

Figure 2. Hub-and-spoke network development (Starkey, 2006).

In Figure 3, larger cities in MIMAROPA - such as Calapan City or Puerto Princesa City-can be denoted as ' $B$ ', or ' $D$ ', with smaller towns, such as Bansud and Terrijos, referred to as ' $o$ ', ' $z$ ', ' $y$ ', and so forth.

The methodology developed for the current study intends to contribute to the knowledge base that tests the idea of polycentric inter-island transport networks in rural archipelagic settings. As noted, MIMAROPA's RDP seeks to improve social inclusiveness by investing in comparatively remote areas that lack good interisland transport. It identified six seaport locations as having potential to facilitate more inter-island connections: Cawit (Marinduque), Pola (Oriental Mindoro), Taytay (Palawan), Cuyo (Palawan), San Jose (Occidental Mindoro) and Looc (Romblon). The current study will help shed light on the prospective effectiveness of such an approach in terms of the impact such investments might have on regional/rural cities and small towns that risk being left behind socioeconomically.

\section{Study on Regional Transport-Related Social Exclusion}

\subsection{Approach}

This article reports on a small study to test the idea that rural communities are at greater risk of social exclusion, relative to larger city counterparts, due to greater difficulties in accessing transport services, and that substantial improvements in inter-island transport opportunities can support increased inclusion opportunities. The study is regionally based, informed by work on mobility and social exclusion by Stanley et al. (2011), Lucas (2011) and Starkey (2006). It is aimed at identifying areas of greater isolation within MIMAROPA and the findings may help support the MITP in mitigating transport-related exclusion and increasing opportunities for social participation.

The methodology developed for this study was a twostage process: first using a survey to collect data that is then used to help inform a gravity model of travel patterns. Both stages are intended to shed light on problems related to remoteness and transport disadvantage. Given that it is only a small study, it provides an indication of the issues and characteristics that are typical of the survey area, which would ideally then be refined by a more comprehensive appraisal.

First, the study collected a small amount of new data to test the expected connection between physical isolation and transport disadvantage. It does this by conducting a customized travel behavior survey in four locations across MIMAROPA: (i) Calapan City, (ii) the Mogpog-Boac conurbation, (iii) Bansud, and (iv) Torrijos (see Figure 1). It also constructs a simplified trip generation/distribution model, using limited passenger data to interpret and manipulate inter-island 'origin-destination' movements for the predominant modes of inter-island

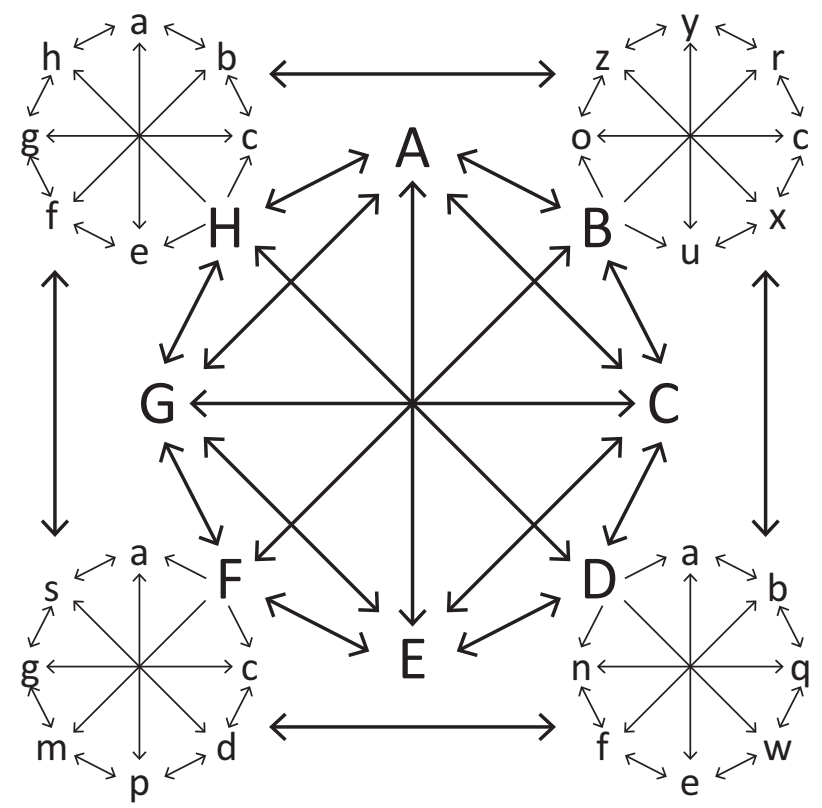

Figure 3. Polycentric network development (Starkey, 2006). 
travel: land transport (by bus/van), or marine transport (by RoRo ferry). The second component draws upon survey and gravity model findings to understand where effective linkages can be provided in MIMAROPA to offer remote communities access to greater opportunities. Although the surveys capture some information on local travel within the four locations sampled, the findings focus on intra-regional travel, as a means to bridge social connections between communities within archipelagic settings.

\subsection{Travel Survey Instrument}

The first stage involved developing a survey instrument to shed light on current travel patterns and perceived problems associated therewith. The survey instrument was adapted from an existing questionnaire that had been developed by two of the current authors and colleagues for an Australian analysis of links between transport disadvantage, social exclusion and well-being (Currie et al., 2009; Stanley et al., 2012). The survey adopts one of five dimensions of social exclusion risk developed by Stanley et al. (2011), this dimension being employment status, partly to ensure surveying was undertaken in safe environments for the interviewers and partly to increase the response rate. Twenty-two questions were selected, modifying the original Australian survey to reflect the different transport modes and different categories of travel behavior within the study areas.

The survey questions were framed around five topics that cover broad aspects of individual travel behavior. To encourage a good response rate, it was intended that participants could respond to the various questions within five minutes. The survey questions covered the following:

(i) last inter-island trip taken (time and day of week they travelled), including details of their origin and destination;

(ii) trips undertaken the day prior to being surveyed, including:

a. the number of trips taken (to aggregate how often people travel within their own environment);

b. the purpose of their trips (to identify the primary reasons for travelling, such as work, education, shopping, recreation, personal business, caring for others and visiting friends and relatives);

c. the modes of transport used (such as ferries, buses, vans and jeepneys, to reveal what modes people depend on and how many modes they use on a given day);

d. the estimated distances travelled (to gain insight into the distances travelled to reach their activities); (iii) perceived importance of transport access (for instance, how much they consider affordability, reliability, independence and options for inter-island travel to be of value to them);

(iv) perceived difficulty in travelling (e.g., whether they feel they can meet transport costs and have options they need for inter-island travel); and,

(v) travel behavior to specific destinations, such as the National Capital Region (Metro Manila), or intraregional destinations within MIMAROPA (e.g., Oriental Mindoro, Occidental Mindoro, Marinduque, Romblon and Palawan).

One factor surrounding the communication of the survey was language: around $50 \%$ of the Philippine population speak English as a second language, with the mother tongues, in most instances Tagalog, coming from a pool of 11 languages and 175 dialects. Within MIMAROPA, fourteen languages are spoken, twelve of which are unique to the region. This prompted the use of multilingual counterparts who could explain the survey to others in both Tagalog and English, both official languages of the Philippines.

An important issue on survey implementation was choice of survey areas within MIMAROPA. These needed to be sufficient to provide a good sense of travel patterns and problems, within the constraints of a small study. The decisions behind site selection were based on the hierarchy of human settlements and the increasing degree of 'remoteness' that is being observed between regional cities and small towns of differing scale across the region. Differences in travel input costs, such as time and money (e.g., related to distance), means that there is a significant variation of trips expected in a comparative assessment between regional cities and small towns. Simply put, greater difficulties in affording and accessing transport is expected to result in fewer intra-regional trips undertaken within a sample from a small town. Conversely, more trips are expected between larger regional cities, where there are likely to be more transport services and intermodal facilities.

As indicated in Figures 4 and 5, two regional cities and two small towns in the Oriental Mindoro and Marinduque provinces were selected for the survey distribution. The National Capital Region is marked to denote its place in the existing hub-and-spoke system as a major interchange point between sampled nodes.

Respondents were targeted inside public administration buildings on weekdays between the hours of 9am and 5pm, as a baseline for the study's sample size. This sampling method captures a specific segment of local populations, where respondents are more likely to be employed and travel as a function of their employment. They are also more likely to be cognizant of their own transport challenges and thus realize and appreciate the importance of travel. Hence, it is likely that individuals who are at the greatest risk of being socially excluded will be unrepresented or under-represented in 


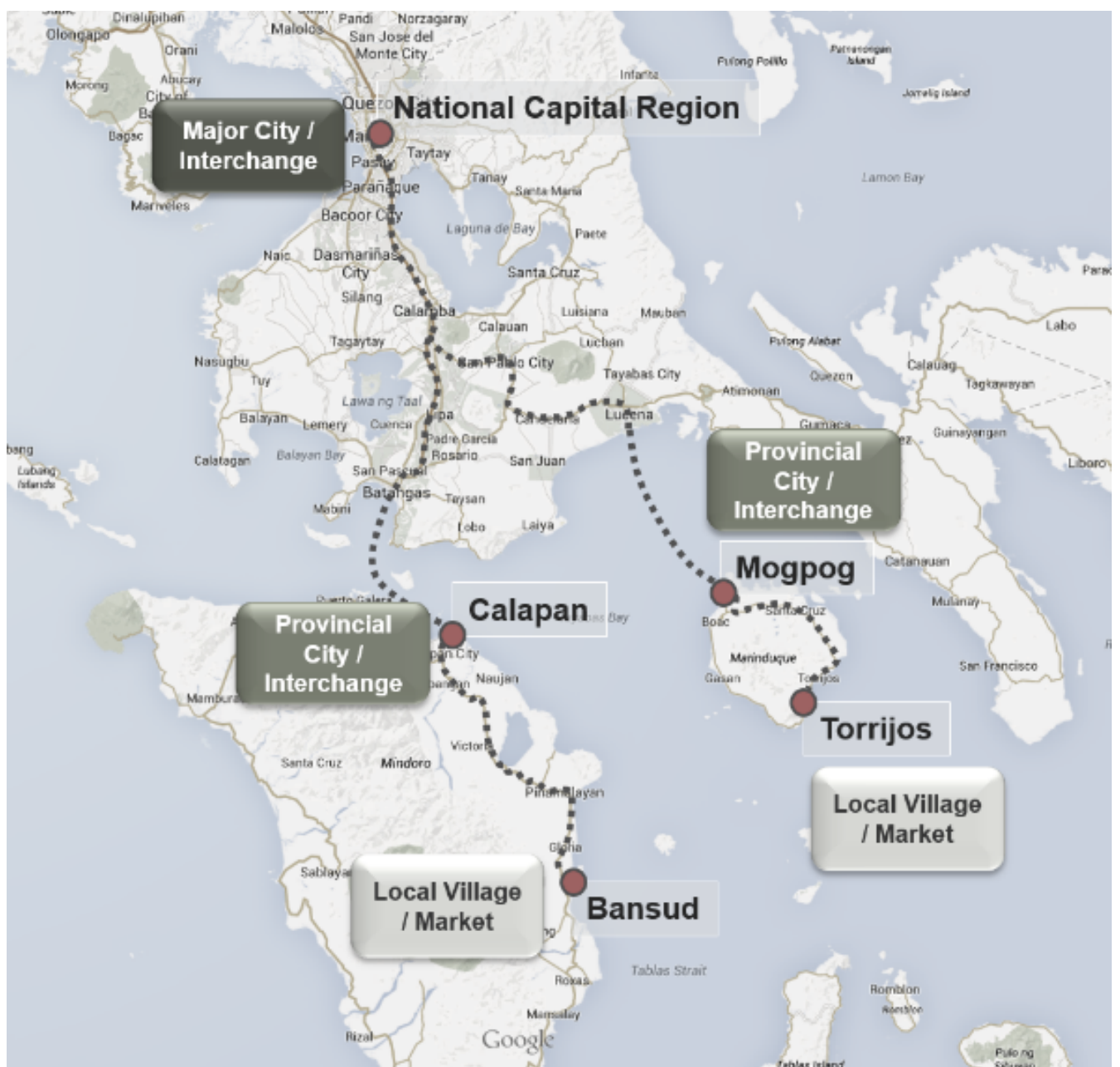

Figure 4. Survey area selection schema based on a hierarchy of cities and towns.

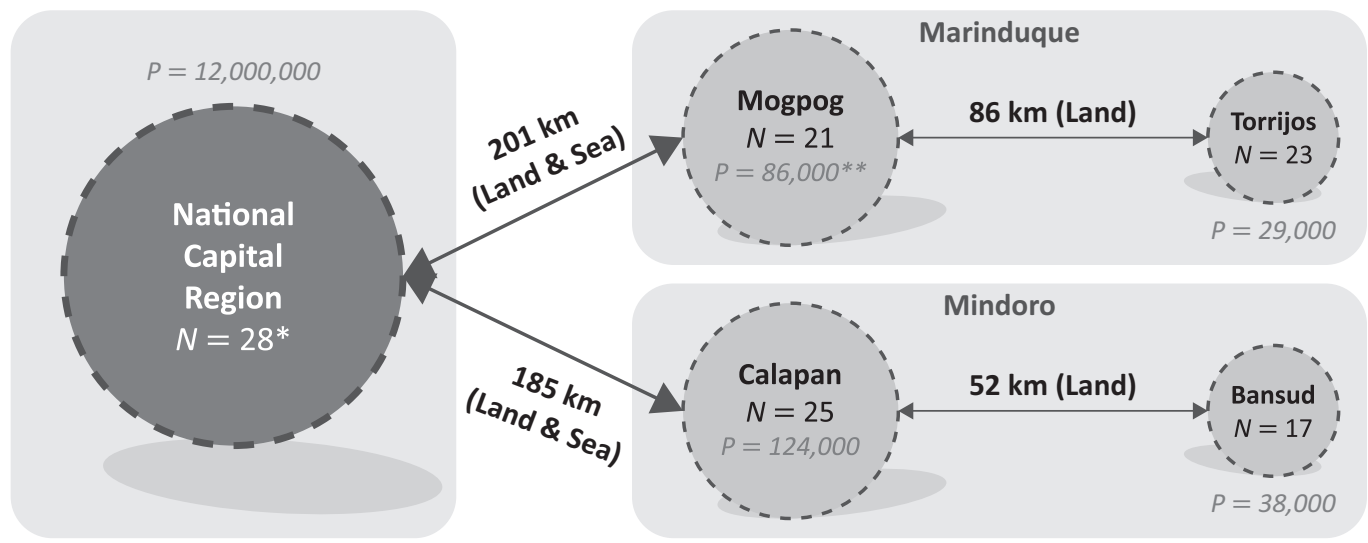

Figure 5. Survey area selection schema based on the study's conceptual framework.

this small sample (due to safety reasons in distributing the survey).

Figure 5 details the number of individual responses that were collected in each survey area: Calapan City $(N=25)$, Mogpog/Boac $(N=21)$, Torrijos $(N=23)$, Bansud $(N=17)$ and the National Capital Region as a reference $(N=28)$, collected over a two week period $(N=114)$.

\subsection{A Gravity Model to Estimate Inter-Island Trip Making}

The second stage involved developing a simplified gravity model to replicate MIMAROPA's pattern of inter-island trip making. Gravity models have long been used in international trade-flow analysis (e.g., Tinbergen, 1962), based on Newton's universal law of gravity. They also 
have a long history in four step urban travel demand modelling, where trip distribution models have commonly been of this type, essentially aiming to replicate urban trip length distribution patterns (see, for e.g., Brady \& Betz, 1971; Jones, 1970).

Tinbergen's work on trade flows estimated exports between pairs of countries as a function of their respective levels of Gross National Product (GNP) and the distance between them, with the respective co-efficient values on GNP and distance all around unity (negative in the distance case). Other studies of the use of the simple gravity model in trade flow analysis have confirmed this broad order of co-efficient values on GNP (such as Head \& Mayer, 2014), with their example for Japan but using GDP rather than GNP. Similarly, values of around -1 for the distance decay parameter have been found in other trade flow analyses, with a reported range between -0.8 and -1.4 (Fernandez, 2014).

Gravity modelling in urban transport demand work has tended to use travel time or even generalized travel cost as the deterrent function, rather than distance, better reflecting the disutility experienced in taking a trip. In longer distance travel modelling, however, distance is often used. Liu et al. (2014), for example, finds a distance decay parameter of -0.8 for inter-urban trips between 370 cities in China and estimates an even higher distance decay parameter of -2 for airline passenger movements. Based on his analyses, Fernandez (2014) argues that there is little to choose between distance and time as the basis for the decay parameter for longer distance passenger travel in Mexico but that travel time (plus cost, if available) is preferred for shorter trips, which accords with practice in many urban gravity modelling applications.

Following Tinbergen's (1962) general approach, the current model assumes that the number of passenger trips between two regions is a function of their scale, reflected by population size (a pull factor), with travel time acting as a deterrent or barrier to trip-making. The model is expressed as:

$$
F=G\left(\frac{m_{1} m_{2}}{r}\right)
$$

where:

- $F$ is the interaction between $m_{1}$ and $m_{2}$ (inbound and outbound trips in this case);

- $G$ is a constant, to be estimated;

- $m_{1}$ and $m_{2}$ are the populations of the origin and destination;

- $r$ is the distance or travel time between the origin and destination (kilometres or minutes).

Following Tinbergen (1962), the present model assumes co-efficient values of unity on population and average travel time. It is important that travel time is modelled instead of distance, as it considers in-vehicle travel time of different modes, as well as wait/transfer times between different modes used throughout a journey.
Distance does not reflect the disutility associated with wait/transfer times. The model used available interisland port-to-port trip data obtained from the Philippine Ports Authority, which records passenger and freight movements annually. This data allows the study to impute water-based travel movements into a trip generation/distribution matrix that can model inter-island interactions between MIMAROPA's five island provinces. This could then be used to estimate prospective demand if new/improved inter-island linkages were to be developed that affect variables in the model (such as in-vehicle travel and wait times between origins and destinations), through iterative calibration techniques. Given the simplicity of the model, there is scope for a more refined approach to take this study further at a later date.

\section{Analysis and Findings}

\subsection{Survey Results}

The survey results reveal some basic information on variables such as travel distance, travel time, travel frequency and trips made the day prior to being surveyed.

The average distance travelled in a respondent's last inter-island journey ranged from a minimum of 66 kilometres to a maximum of 1,291 kilometres, with a mean distance of 284 kilometres.

Average inter-island travel times ranged from a minimum of 2 hours to a maximum of 16 hours. The average omits two outlying responses where respondents had identified international destinations by plane in their response, which skewed the analysis. Interestingly, the mean inter-island travel time calculated for a respondent is 7.92 hours, with a standard deviation of 3.6 hours. Thus, for a mean distance travelled of 284 kilometres, the implicit typical speed of inter-island trips is around 35 kilometres per hour. This illustrates the slow nature of travel throughout the region, due to factors such as a need for long intermodal transfers at interchange nodes (for example from bus, van or jeepney to ferry) and slowmoving transport, such as RoRo ferries.

In terms of inter-island trip frequency, the last time a respondent had left their island ranged from a minimum of 1 day ago to a maximum of 1,370 days ago, with the mean value being 95 days. This suggests that respondents, on average, travel to a destination outside their island around once every three months. The positively skewed distribution of trip frequency data suggests that some respondents have not left their island for a long time (i.e. years).

Information on trips made the day prior to being surveyed was collected, to inform the nature of local trip making. The mean number of return trips made the day before was 2.6. This is in line with expectations, giving some comfort to the validity of survey responses. As expected, the main trip purpose was work-related, with 55 respondents out of the total sample of 87 (63\%), listing work as one of their reasons for travel. It is noted that a 
number of respondents did not leave their homes in the Mogpog sample (denoted as ' 0 ' trips undertaken 'yesterday'), where the previous day fell on a national public holiday (Eid-al-Fitr Day).

By consolidating the data of four samples into two sets, one representing regional cities (Calapan City and Mogpog/Boac) and the other representing smaller townships (Bansud and Torrijos), the study is able to enhance the statistical strength of its samples for comparative analysis (see Table 1).

The comparison of statistical mean values between cities and townships in Table 1 also meets a test of sensibility: it shows that residents of smaller towns, relative to their larger city counterparts, need to travel greater distances, take more time to travel, make fewer inter-island trips and take more transport modes, due to additional intermodal transfers required.

Despite limitations in being able to obtain a larger sample size across a wider area, the survey data collected allowed for significant associations to be found through bivariate correlation analysis. Table 2 shows eight significant relationships with confidence intervals greater than 95\% (two-tailed test), and the corresponding inferences that are linked with socio-spatial transport disadvantage.

The findings in Table 2 relate strongly to this study's focus on the risks of social exclusion through transport disadvantage. This includes the importance of independent travel and the sense of personal mastery or control it affords to individuals. The analysis strongly suggests that when a respondent finds it more difficult to access transport, both inter-island and local, they take fewer trips. Similarly, if travel costs increase and it becomes more difficult for a respondent to find appropriate transport services, this makes it harder for them to undertake desired trips. Subsequently, the reliance on others for travel also increases, which negatively influences the total number of trips a respondent seeks to make to another island destination. These findings suggest that people from small rural communities are at greater risk of social exclusion, relative to their larger city counterparts, due to greater difficulties in accessing non-local transport.

Another key finding relates to the concept of independent travel. The survey findings reveal that if a respondent's dependency on others is increased, say, through the need for a driver in a remote area to take them places, then that respondent is less likely to travel.
The feeling of empowerment a respondent has in being able to undertake inter-island travel, to get to places quickly, to have transport options and to be able to travel when they want to cannot be ignored in the context of this study, as individual well-being has been shown to be linked to an individual's sense of personal mastery, which is supported by the capacity for independent travel (Stanley et al., 2011).

\subsection{Gravity Model Configuration and Observations}

The gravity model is separate to the survey work and allows origin-destination trips to be estimated across the region. Its input and output variables are set out in Table 3 for key intra-regional pairs, using limited secondary origin-destination (O-D) port data obtained from seaport administrations in 2014. The model is used to estimate the remaining $O-D$ pairs. It is important to note that the model features a manual 'proportional fitting' technique, which requires a constant value to be defined within its formula. To this end, the study has assigned the constant value of ' $G$ ' in Formula (1) to be 0.0165 , which appears to best fit with obtained passenger statistics for various inter-island flows (these being flows between Calapan City-Batangas City and Calapan City-Metro Manila). To complete the model, origindestination populations and estimated travel times have been input into the rest of the formula, to calculate the total number of inter-island trips occurring throughout MIMAROPA. Travel times between $m_{1}$ and $m_{2}$ to estimate to value of ' $r$ ' takes into account all modes used to complete a journey within an O-D pair (for example, the travel times of all known RoRo/fast ferry and bus/van services are calculated as an average for every modal segment in a journey), route length (on land or on water), and average wait times to transfer between modes to complete a journey (calculated by dividing the total number of published services over a 24 hour weekday). Journeys to Puerto Princesa City involve the use of intermodal flights (shown in Figure 6), due to a lack of formalized ferry services between Palawan and other provinces and O-D pair distances that well exceed the region's mean. As the majority of destinations in the study area are headed for the National Capital Region and Batangas City, they are also represented in Table 3 and shown in Figure 6.

Table 1. Mean statistics for regional cities vs. small townships.

\begin{tabular}{llc}
\hline Trip descriptor & Regional city $(\boldsymbol{N}=\mathbf{4 6})$ & Small township $(\boldsymbol{N}=\mathbf{4 0})$ \\
\hline & & Mean statistic \\
\hline Distance from origin to destination & 202 kilometres & 380 kilometres \\
Travel time & 5.98 hours & 10.21 hours \\
Last inter-island trip made & 84.69 days & 110.94 days \\
Number of return trips made 'yesterday' & 2.57 trips & 2.63 trips \\
Number of trip modes used 'yesterday' & 1.24 modes & 1.80 modes \\
Number of provinces travelled to within the last year & 3.11 provinces & 3.03 provinces \\
\hline
\end{tabular}


Table 2. Significant relationships in the bivariate correlation analysis

\begin{tabular}{|c|c|c|c|c|}
\hline Variable A & Variable B & $\begin{array}{l}\text { Pearson Corr } \\
\text { between A a } \\
\text { Sig. (2-tailed) }\end{array}$ & $\begin{array}{l}\text { lation } \\
\text { d B and }\end{array}$ & Inferences between A and B \\
\hline $\begin{array}{l}\text { 1. How easy or hard } \\
\text { people find it to access } \\
\text { transport }\end{array}$ & $\begin{array}{l}\text { Total trips made } \\
\text { yesterday }\end{array}$ & -0.338 & 0.003 & $\begin{array}{l}\text { When a person finds it harder to } \\
\text { access transport, they take fewer } \\
\text { trips. }\end{array}$ \\
\hline $\begin{array}{l}\text { 2. Importance of } \\
\text { independence from } \\
\text { others for transport }\end{array}$ & $\begin{array}{l}\text { Total trips made } \\
\text { yesterday }\end{array}$ & -0.274 & 0.025 & $\begin{array}{l}\text { When a person is increasingly } \\
\text { dependent on others for travel, } \\
\text { they take fewer trips. }\end{array}$ \\
\hline $\begin{array}{l}\text { 3. How easy or hard } \\
\text { people find it to pay } \\
\text { for transport costs }\end{array}$ & $\begin{array}{l}\text { Importance of having } \\
\text { options to travel }\end{array}$ & 0.240 & 0.047 & $\begin{array}{l}\text { When a person finds it harder to pay } \\
\text { for transport costs, they place } \\
\text { greater importance on having more } \\
\text { travel options and more affordable } \\
\text { transport services. }\end{array}$ \\
\hline $\begin{array}{l}\text { 4. Importance of } \\
\text { independence from } \\
\text { others for transport }\end{array}$ & $\begin{array}{l}\text { Importance of } \\
\text { affordability, getting } \\
\text { to places quickly, } \\
\text { options and } \\
\text { on-demand travel }\end{array}$ & $0.445-0.644$ & 0.000 & $\begin{array}{l}\text { The importance of independent travel } \\
\text { is linked to affordability, efficiency, } \\
\text { travel choices and travel availability. } \\
\text { All of these factors can support a } \\
\text { sense of personal mastery. }\end{array}$ \\
\hline $\begin{array}{l}\text { 5. How easy or hard } \\
\text { people find it to get } \\
\text { to places quickly }\end{array}$ & $\begin{array}{l}\text { Importance of being } \\
\text { able to get around } \\
\text { reliably and how easy } \\
\text { or hard it is to pay for } \\
\text { transport costs }\end{array}$ & $0.281-0.584$ & $0.031-0.000$ & $\begin{array}{l}\text { People that find it harder to reach } \\
\text { places quicker place more } \\
\text { importance on reliability and } \\
\text { transport costs. }\end{array}$ \\
\hline $\begin{array}{l}\text { 6. How easy or hard } \\
\text { it is to travel when a } \\
\text { person wants to }\end{array}$ & $\begin{array}{l}\text { How easy or hard it is } \\
\text { to pay for costs of } \\
\text { travel, getting to places } \\
\text { quickly and accessing } \\
\text { transport services }\end{array}$ & $0.517-0.674$ & 0.000 & $\begin{array}{l}\text { People find it harder to travel when } \\
\text { they are unable to pay for transport } \\
\text { and when transport services are } \\
\text { not available. }\end{array}$ \\
\hline $\begin{array}{l}\text { 7. How often a person } \\
\text { travels to another } \\
\text { island province in } \\
\text { MIMAROPA per year }\end{array}$ & $\begin{array}{l}\text { How easy or hard it is } \\
\text { to travel when a } \\
\text { person wants to }\end{array}$ & -0.246 & 0.045 & $\begin{array}{l}\text { The easier a person finds it to travel, } \\
\text { the more likely they are to } \\
\text { undertake inter-island travel within } \\
\text { the region. }\end{array}$ \\
\hline $\begin{array}{l}\text { 8. How often a person } \\
\text { travels to the National } \\
\text { Capital Region per year }\end{array}$ & $\begin{array}{l}\text { How often a person } \\
\text { travels to another } \\
\text { island province in } \\
\text { MIMAROPA per year }\end{array}$ & 0.247 & 0.025 & $\begin{array}{l}\text { When a person visits the National } \\
\text { Capital Region more frequently, the } \\
\text { more likely they are to also travel to } \\
\text { other island provinces in MIMAROPA. }\end{array}$ \\
\hline
\end{tabular}

Table 3 and Figure 6 show that intra-regional trip volumes within MIMAROPA (discounting O-D pairs to Puerto Princesa City due to reliance on air travel), are some of the lowest in the matrix (for example, Calapan City to Odiongan or Boac and Boac to Odiongan), when compared to trips bound for destinations outside the region (for example, Calapan City, Boac or Odiongan to Metro Manila or Batangas City). Despite short geographic distances between some of MIMAROPA's provinces, the actual travel distances between them are much longer, because out-of-region intermodal transfers are required to reach neighboring island provinces in the broader hub-and-spoke network. For example, trips from Calapan City to Boac typically require a passenger to transfer between land and sea modes at Batangas City and Lucena, both critical interchanges in the established network, making the overall journey time around 7.8 hours. Similarly, journey times between Calapan City and Odiongan are also long (around 20.5 hours, due to infrequent services at the interchange node in Batangas City), impacting on patronage levels in the gravity model (estimated at only 2,417 trips per annum in 2014).

\subsection{Alternative Gravity Model with Prioritized Ports Activated}

The travel time variable in the gravity model can be changed to reflect an increase in direct port-to-port ser- 
Table 3. Gravity model results for MIMAROPA in 2014.

\begin{tabular}{|c|c|c|c|c|c|}
\hline $\begin{array}{l}\text { Proportional } \\
\text { fitting }\end{array}$ & $\begin{array}{l}\text { Origin } \\
\text { (population) }\end{array}$ & $\begin{array}{l}\text { Destination } \\
\text { (population) }\end{array}$ & $\begin{array}{l}\text { Distance between } \\
m_{1} \text { and } m_{2}\end{array}$ & $\begin{array}{l}\text { Travel time between } \\
m_{1} \text { and } m_{2}\end{array}$ & $\begin{array}{l}\text { Annual number of trips } \\
\text { between } m_{1} \text { and } m_{2}\end{array}$ \\
\hline G (constant) & $m_{1}$ & $m_{2}$ & & $r$ & $\boldsymbol{F}$ \\
\hline 0.0165 & $\begin{array}{l}\text { Calapan City, } \\
\text { Oriental } \\
\text { Mindoro } \\
(785,602)\end{array}$ & $\begin{array}{l}\text { Metro Manila, } \\
\text { National } \\
\text { Capital Region } \\
(11,855,975)\end{array}$ & 185 kilometres & 283 minutes & $(1,918,894)$ \\
\hline 0.0165 & $\begin{array}{l}\text { Calapan City, } \\
\text { Oriental } \\
\text { Mindoro } \\
(785,602)\end{array}$ & $\begin{array}{l}\text { Batangas City } \\
(2,377,395)\end{array}$ & 79 kilometres & 130 minutes & $(1,823,481)$ \\
\hline 0.0165 & $\begin{array}{l}\text { Calapan City, } \\
\text { Oriental } \\
\text { Mindoro } \\
(785,602)\end{array}$ & $\begin{array}{l}\text { Boac, } \\
\text { Marinduque } \\
(229,636)\end{array}$ & 231 kilometres & 468 minutes & 13,590 \\
\hline 0.0165 & $\begin{array}{l}\text { Calapan City, } \\
\text { Oriental } \\
\text { Mindoro } \\
(785,602)\end{array}$ & $\begin{array}{l}\text { Odiongan, } \\
\text { Romblon } \\
(283,930)\end{array}$ & 232 kilometres & 1234 minutes & 2,417 \\
\hline 0.0165 & $\begin{array}{l}\text { Calapan City, } \\
\text { Oriental } \\
\text { Mindoro } \\
(785,602)\end{array}$ & $\begin{array}{l}\text { Puerto Princesa } \\
\text { City, Palawan } \\
(771,667)\end{array}$ & 775 kilometres & 421 minutes & 56,435 \\
\hline 0.0165 & $\begin{array}{l}\text { Boac, } \\
\text { Marinduque } \\
(229,636)\end{array}$ & $\begin{array}{l}\text { Metro Manila, } \\
\text { National } \\
\text { Capital Region } \\
(11,855,975)\end{array}$ & 204 kilometres & 394 minutes & 289,380 \\
\hline 0.0165 & $\begin{array}{l}\text { Boac, } \\
\text { Marinduque } \\
(229,636)\end{array}$ & $\begin{array}{l}\text { Batangas City } \\
(2,377,395)\end{array}$ & 152 kilometres & 338 minutes & 78,848 \\
\hline 0.0165 & $\begin{array}{l}\text { Boac, } \\
\text { Marinduque } \\
(229,636)\end{array}$ & $\begin{array}{l}\text { Odiongan, } \\
\text { Romblon } \\
(283,930)\end{array}$ & 463 kilometres & 1442 minutes & 517 \\
\hline 0.0165 & $\begin{array}{l}\text { Boac, } \\
\text { Marinduque } \\
(229,636)\end{array}$ & $\begin{array}{l}\text { Puerto Princesa } \\
\text { City, Palawan } \\
(771,667)\end{array}$ & 843 kilometres & 562 minutes & 9,257 \\
\hline 0.0165 & $\begin{array}{l}\text { Odiongan, } \\
\text { Romblon } \\
(283,930)\end{array}$ & $\begin{array}{l}\text { Metro Manila, } \\
\text { National } \\
\text { Capital Region } \\
(11,855,975)\end{array}$ & 416 kilometres & 1227 minutes & 36,893 \\
\hline 0.0165 & $\begin{array}{l}\text { Odiongan, } \\
\text { Romblon } \\
(283,930)\end{array}$ & $\begin{array}{l}\text { Batangas City } \\
(2,377,395)\end{array}$ & 333 kilometres & 1104 minutes & 9,138 \\
\hline 0.0165 & $\begin{array}{l}\text { Odiongan, } \\
\text { Romblon } \\
(283,930)\end{array}$ & $\begin{array}{l}\text { Puerto Princesa } \\
\text { City, Palawan } \\
(771,667)\end{array}$ & 832 kilometres & 1395 minutes & 1,858 \\
\hline
\end{tabular}

Note: The trip numbers in brackets closely reproduce statistical data obtained by the Philippine Ports Authority. 


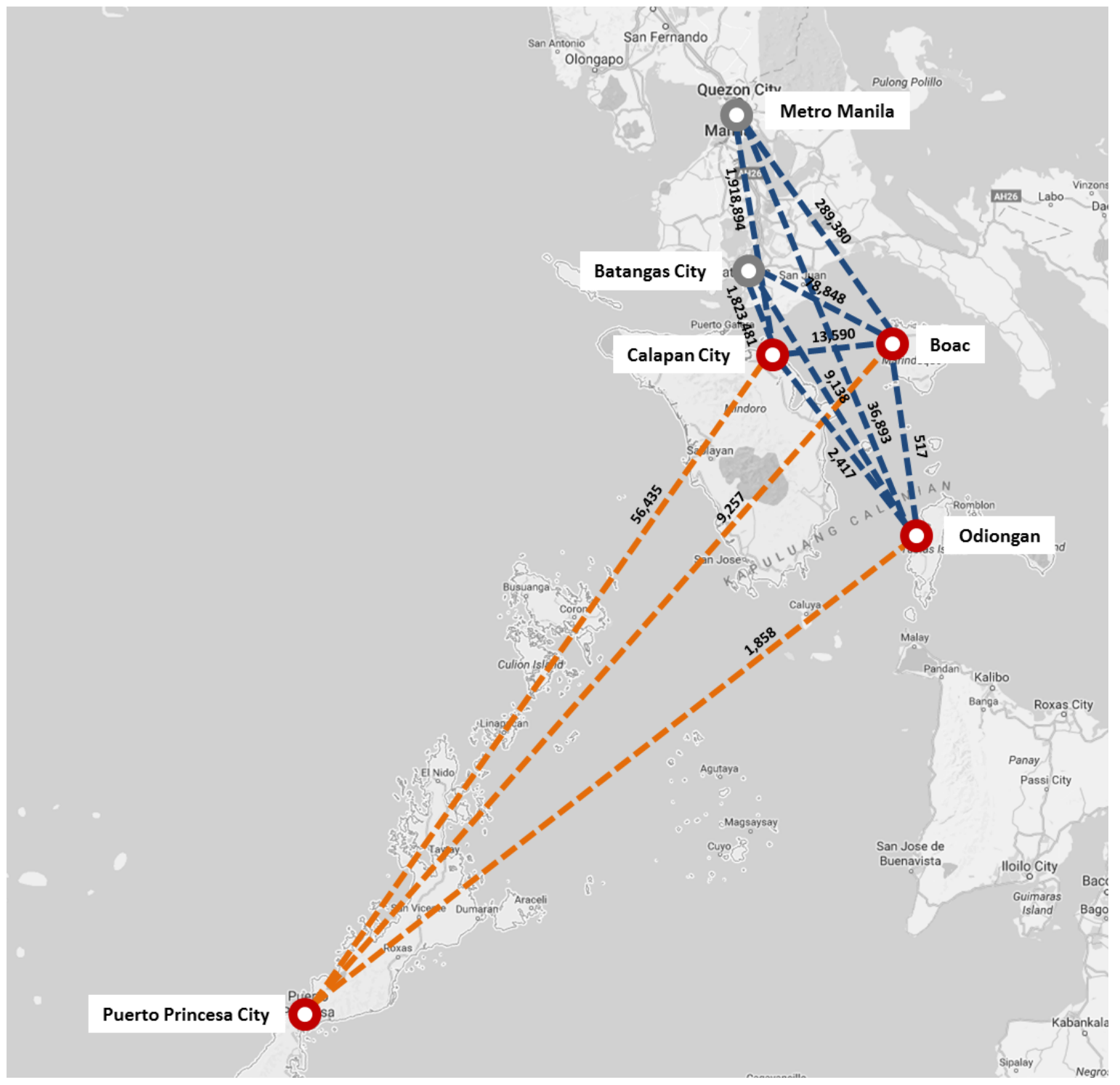

Figure 6. Selected gravity model trip distribution for MIMAROPA.

vices to facilitate a localized polycentric transport network that supports MIMAROPA's RDP objectives and bridges social capital. The model can then estimate the additional number of trips generated with each new (faster/shorter) connection. Table 4 estimates the additional volume of trips generated with the inclusion of 20 RoRo services per day for selected O-D pairs that best reduce intra-regional travel times and reduce the number of required intermodal transfers for smaller/rural townships.

The alternative gravity model suggests that activating parts of a localized polycentric transport network can substantially reduce travel times and generate new trips, promoting stronger regional integration and reducing the risk of transport-related social exclusion in small townships. For example, a point-to-point connection between Boac and Odiongan can reduce average travel times by 18 hours and generate an estimated 12,114 trips, which is around 23 times greater than existing volumes. Similarly, notable increases in trip volumes and re- ductions in average travel times can be found for Calapan City to Odiongan and Calapan City to Boac (see Table 4). With the three port-to-port linkages from Table 4 activated (with an evenly distributed service frequency of 20 RoRo services per day), MIMAROPA's intraregional trip volumes are projected to increase substantially, from 16,524 trips per annum to 86,972 trips per annum. Figure 7 illustrates the differences in trip volumes for these $O-D$ pairs through the existing and alternative gravity models.

\section{Discussion and Conclusions}

This study's travel survey provides support for an association between improved personal travel opportunities, for inter-island travel and connecting local trip making, and a reduced risk of transport-related social exclusion. It has highlighted mobility barriers faced by residents of more remote islands, drawing attention to some of MIMAROPA's socio-spatial challenges in transport terms. 
Table 4. Alternative gravity model results.

\begin{tabular}{|c|c|c|c|c|c|c|}
\hline Origin & Destination & $\begin{array}{l}\text { Existing number } \\
\text { of trips } \\
\text { generated } \\
\text { between } \\
\text { O-D pair }\end{array}$ & $\begin{array}{l}\text { Annual new number } \\
\text { of trips generated } \\
\text { between O-D pair } \\
\text { with } 20 \text { direct RoRo } \\
\text { services per day }\end{array}$ & $\begin{array}{l}\text { Existing } \\
\text { O-D } \\
\text { travel } \\
\text { time }\end{array}$ & $\begin{array}{l}\text { New O-D } \\
\text { travel } \\
\text { time }\end{array}$ & $\begin{array}{l}\text { Reduction } \\
\text { in O-D } \\
\text { travel } \\
\text { time }\end{array}$ \\
\hline $\begin{array}{l}\text { Boac, } \\
\text { Marinduque }\end{array}$ & $\begin{array}{l}\text { Odiongan, } \\
\text { Romblon }\end{array}$ & 517 & 12,114 & $\begin{array}{l}1,442 \\
\text { minutes }\end{array}$ & $\begin{array}{l}327 \\
\text { minutes }\end{array}$ & $\begin{array}{l}1,115 \\
\text { minutes }\end{array}$ \\
\hline $\begin{array}{l}\text { Calapan City, } \\
\text { Oriential } \\
\text { Mindoro }\end{array}$ & $\begin{array}{l}\text { Boac, } \\
\text { Marinduque }\end{array}$ & 13,590 & 39,939 & $\begin{array}{l}468 \\
\text { minutes }\end{array}$ & $\begin{array}{l}273 \\
\text { minutes }\end{array}$ & $\begin{array}{l}195 \\
\text { minutes }\end{array}$ \\
\hline $\begin{array}{l}\text { Calapan City, } \\
\text { Oriential } \\
\text { Mindoro }\end{array}$ & $\begin{array}{l}\text { Odiongan, } \\
\text { Romblon }\end{array}$ & 2,417 & 34,919 & $\begin{array}{l}1,234 \\
\text { minutes }\end{array}$ & $\begin{array}{l}327 \\
\text { minutes }\end{array}$ & $\begin{array}{l}907 \\
\text { minutes }\end{array}$ \\
\hline
\end{tabular}

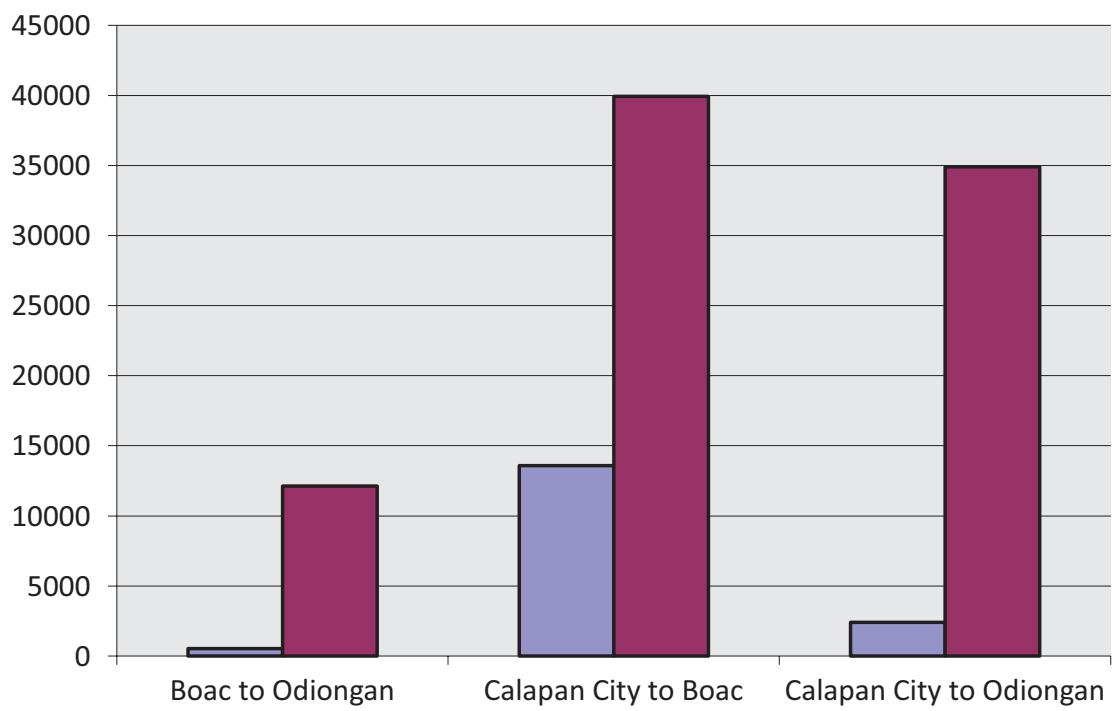

Existing number of trips generated (per annum)

- Trips generated with a direct inter-island connection (per annum)

Figure 7. Existing and alternative inter-island trip volumes for MIMAROPA.

This has been supported by the development of a simplified gravity model that highlights the way poor travel opportunities, such as indirect connections, pose a constraint to inter-island travel, particularly for residents of smaller islands. The survey results draw attention to the importance of inter-island travel where improvements to these transport services will be likely to improve opportunities for some people at risk of social exclusion. It will be important to also address local land transport to improve connections to the ports, as part of a process of building bridging social capital and thus social inclusion. The improvement of local transport will also have the added value of increasing the capabilities of those not wishing to travel between islands but participate in a local economy and social opportunities.

The projected increase in inter-island trips in the alternative gravity model suggests that there is potential for improved social and economic participation if intraregional travel times/distances are reduced, as part of the government's suggested improvement strategy to activate inter-island trips (NEDA, 2014). However, there is some question about whether the projected increase in travel volumes will be sufficient to entice private operators to provide more formalized water-based services on a fully commercial basis. Arguably, where the gravity model estimates origin-destination movements at, say, 100,000 per year or greater, private operators are more likely to ply regular and frequent inter-island services to support these trips, as they currently do from Calapan City and Boac to Metro Manila, Batangas City and Lucena (see Figure 6).

However, the significance of trip growth modelled in Figure 7, as a result of new links and services, should not be ignored. For social exclusion to be addressed, the establishment and implementation of minimum interisland service levels may be required (for example, 20 ferry services per day), to guarantee access for those at risk of being excluded in remote areas. This approach is sometimes taken in setting urban public transport base service levels. The government should consider calling for expressions of interest to provide affordable intraregional transport services, with proponents to indicate 
the scale and nature of any assistance that might be required to do so. This level of assistance can be considered by government, alongside its assessment of the benefits of increased social and economic participation by relatively socially excluded communities, in deciding whether to proceed with the initiative.

The survey/gravity model study methodology can be refined and applied more widely in the region, providing MIMAROPA's RDP and other regions within the Philippines with a basic methodology to identify locations of significant socio-spatial disadvantage and groups likely to be at risk of exclusion because of poor transport opportunities. The gravity model can also help in the assessment of the economics of transport service improvements, through its capacity to project how trip making might change under improved travel circumstances. Increasing sample sizes and expanding the sampling method to capture a wider range of demographic segments at greater risk of social exclusion, such as those who do not have adequate or sufficient employment or people/areas with comparatively high levels of poverty incidence, should be early priorities. As part of this process, the survey should be applied in more remote settlements, such as interior communities, where social assessments may be undocumented. Finally, a refinement of the approach to this study should allow for additional variables to be modelled, such as land and air-based transport modes.

The work that is discussed in this article is of considerable importance to the Philippines if it is to join the international movement for achieving the Sustainable Development Goals. Understanding the local issues that facilitate barriers to the achievement of economic, social and environmental outcomes is necessary in order to understand actions needed for goal achievement. This article's methodology presents a simple and practical way to gain insights into transport network limitations in areas where critical transport data is incomplete. It should also be useful in shedding light on transport elements of international development efforts in other archipelagic countries, such as Indonesia, Fiji, the Solomon Islands, Vanuatu and Papua New Guinea. More broadly in the Philippines, similar investigations of this scale could be exercised in Samar, Leyte and Mindanao-Sulu areas, if political and security conditions allow. Armed with this knowledge, the Philippines will be able to join in the international collaborative partnerships being formed to support and assist in target outcomes, along with some some 114 nations that have already sought the United Nations' help in localizing implementation efforts (Birch, 2017). Indeed, transport policy can be used as a pivotal force to achieve desired economic, social and environmental outcomes, particularly through the reduction of social exclusion (Stanley, 2016).

\section{Acknowledgements}

Andrew Collins from the University of Sydney Business School and Romeo C. Escandor, Susan Sumbeling, Mar- ian Cunanan and Sheryll Sarabia from the National Economic and Development Authority (MIMAROPA Region).

\section{Disclaimer and Conflict of Interests}

The views and opinions expressed in this article are those of the authors and do not reflect the official policy or position of Transport for New South Wales and the National Economic and Development Authority (MIMAROPA Region). The authors declare no conflict of interests.

\section{References}

Asian Development Bank. (2010). Bridges across Oceans: Initial impact assessment of the Philippines nautical highway system and lessons for South East Asia. Asian Development Bank. Retrieved from: https:// www.adb.org/sites/default/files/publication/27510/ bridges-oceans.pdf

Birch, E. (2017). Is there any hope of aligning the many efforts working on the SDGs? Citiscope. Retrieved from http://citiscope.org/commentary/2017/07/there-any -hope-aligning-many-efforts-working-sdgs?utm_sour ce=Citiscope\&utm_campaign=7a29b46f21-Mailchimp _2017_09_05\&utm_medium=email\&utm_term=0_ ce992dbfef-7a29b46f21-118045105

Brady, C., \& Betz, M. (1971). An evaluation of regression analysis and the gravity model in the Phoenix urban area. Journal of Transport Economics and Policy, 5(1), 76-90.

Cass, N., Shove, E., \& Urry, J. (2005). Social exclusion, mobility and access. The Sociological Review, 53(3), 539-555.

Cervero, R., \& Golub, A. (2007). Informal transport: A global perspective. Transport Policy, 14(6), 445-457.

Church, A., Frost, M., \& Sullivan, K. (2000). Transport and social exclusion in London. Transport Policy, 7(3), 195-205.

Currie, C., Richardson, T., Smyth, P., Vella-Broderick, D., Hine, J., Lucas, K., . . . Stanley, J. (2009). Investigating links between transport disadvantage, social exclusion and well-being in Melbourne: Preliminary results. Transport Policy, 16(3), 97-105.

Fernandez, R. (2014). Gravity, distance and traffic flows in Mexico. Research in Transportation Economics, 46(October), 30-35.

Francisco, K. (2017). The impacts of roll-on/roll-off transport system in the Philippines. Discussion Paper Series No. 2017-22. Quezon City: Philippines Institute for Development Studies.

Head, K., \& Mayer, T. (2014). Gravity equations: Workhorse, toolkit and cookbook. In G. Gopinath, E. Helpman, \& K. Rogoff (Eds.), Handbook in international economics. Oxford: Elsevier.

Jones, I. (1970). Gravity models and generated traffic: A note. Journal of Transport Economics and Policy, 2(4), 208-211.

Kramar, H., \& Kadi, J. (2013). Polycentric city networks in 
Central-Eastern Europe: Existing concepts and empirical findings. Geographia Polonica, 86(3), 183-198.

Levitas, R., Pantazis, C., Fahmy, E., Gordon, D., Lloyd, E., \& Patsios, D. (2007). The multi-dimensional analysis of social exclusion. Bristol, UK: University of Bristol.

Llanto, G. (2016). Philippines infrastructure and connectivity: Challenges and reforms. Asian Economic Policy Review, 11, 243-261.

Lucas, K. (2011). Transport and social exclusion: Where are we now? Transport Policy, 20, 105-113.

Marta, S., \& Akhmouch, A. (2017). This form of city-tocity cooperation is starting to drive SDGs implementation. Citiscope. Retrieved from: http://citiscope. org/commentary/2017/08/form-city-city-cooperation -starting-drive-sdgs-implementation?utm_source $=$ Citi scope\&utm_campaign $=5685 \mathrm{~d} 6$ a392-Mailchimp_20 17_08_29\&utm_medium=email\&utm_term=0_ce99 2dbfef-5685d6a392-118045105

National Economic and Development Authority. (2014). MIMAROPA Regional Development Plan 2013-2016. National Economic and Development Authority. Retrieved from http://mimaropa.neda.gov.ph/ mimaropa-regional-development-plan-2013-2016

National Economic and Development Authority. (2016). Statement on full year 2015 official poverty statistics. National Economic and Development Authority. Retrieved from http://www.neda.gov.ph/2016/10/ 27/statement-on-full-year-2015-official-poverty-stat istics-as-delivered-by-dir-reynaldo-r-cancio-of-neda

Philippine Institute for Development Studies. (2016). Why Inequality matters in poverty reduction and why the middle class needs policy attention. Philippine Development Studies. Retrieved from https:// dirp4.pids.gov.ph/websitecms/CDN/PUBLICATIONS/ pidsdps1555_rev.pdf

Philippine Statistics Authority. (2017). Population of Region IV-B-MIMAROPA. Philippine Statistics Authority. Retrieved from http://psa.gov.ph

Piachaudt, T., LeGrand, J., \& Piachaud, D. (2002). Degrees of exclusion: Developing a dynamic, multidimensional measure. In J. Hills, J. LeGrand, \& D. Piachaud (Eds.), Understanding social exclusion (pp. 30-43). Oxford: Oxford University Press.

Roxas, R., \& Fillone, A. (2016). Establishing value of time for the inter-island passenger transport of the Western Visayas region, Philipines. Transportation, 43(4), 661-676.

Sen, A. (1999). Development as freedom. New York: Oxford University Press.

Simon, D., \& Arfvidsson, H. (2015). Pilot project to test potential targets and indicators for the Ur- ban Sustainable Development Goal 11: Final report. Urban Futures. Retrieved from http://www.mistra urbanfutures.org/en/node/1208

Stanley, J. (2016). Cities of the future: What should be their form? MSSI Issues Paper No. 7. Melbourne: Melbourne Sustainable Society Institute, University of Melbourne.

Stanley, J., Stanley, J., \& Davis, S. (2014). Connecting neighbourhoods: The 20 minute city, Bus and Coach Industry Policy Paper 4. Canberra: Bus Industry Confederation.

Stanley, J. K., Stanley, J. R., \& Hensher, D. (2012). Mobility, social capital and sense of community: What value? Urban Studies, 29(16), 3595-3609.

Stanley, J. K., Hensher, D., Stanley, J., \& Vella-Brodrick, D. (2011). Mobility, social exclusion and well-being: Exploring the links. Transportation Research Part A: Policy and Practice, 45(8), 789-801.

Starkey, P. (2006). The rapid assessment of rural transport services. Intermediate Technology Consultants. Retrieved from http://www.animaltraction.com/ StarkeyPapers/Starkey-AssessingRuralTransport-Draft 060315.pdf

Stone, W., Gray, M., \& Hughes, J. (2003). Social capital at work: How family, friends and civic ties relate to labour market outcomes. Research paper no. 31. Melbourne: Australian Institute of Family Studies.

Tinbergen, J. (1962). An analysis of world trade flows. In J. Tinbergen (Ed.), Shaping the world economy: Suggestions for an international economic policy. New York: Twentieth Century Fund. Retrieved from https://repub.eur.nl/pub/16826

United Nations Development Programme. (2013). United Nations Development Programme in the Philippines. United Nations Development Programme. Retrieved from http://www.ph.undp.org/ content/philippines/en/home.html

United Nations. (2017). Sustainable development goals. Sustainable Development Goals. Retrieved from http://www.un.org/sustainabledevelopment/sustain able-development-goals

UN-Habitat. (2013). Streets as public spaces and drivers of urban prosperity. Nairobi, Kenya: UN-HABITAT.

Vella-Brodrick, D., \& Stanley, J. (2013). The significance of transport mobility in predicting well-being. Transport Policy, 29, 236-242.

Liu, Y., Sui, Z., Kang, C., \& Gao, Y. (2014). Uncovering patterns of inter-urban trip and spatial interaction from social media check-in data. PLOS One. Retrieved from https://doi.org/10.1371/journal.pone.0086026 


\section{About the Authors}

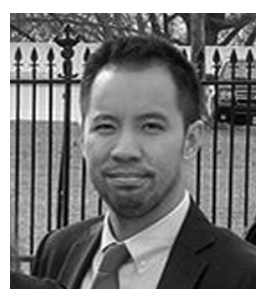

David Cao is a Transport Planner at Transport for New South Wales (TfNSW). He previously served as an Australian Youth Ambassador for Development (AYAD) in the Philippines, with the National Economic and Development Authority-MIMAROPA Region (NEDA MIMAROPA), to develop rural transport strategies focusing on inter-island transport network development, trade and social inclusion.

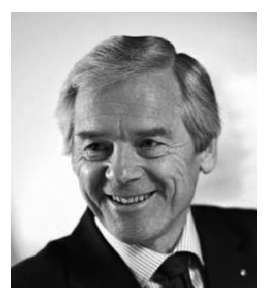

John Stanley is an Adjunct Professor at the Institute of Transport and Logistics Studies (ITLS) at University of Sydney Business School. He is a former Deputy Chair of Australia's National Road Transport Commission. John has published widely on transport and land use policy and planning and is co-author of the books, An Introduction to Transport Policy and How Great Cities Happen.

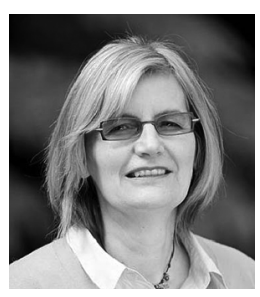

Janet Stanley is a Principal Research Fellow at the Melbourne Sustainable Society Institute, Faculty of Design, the University of Melbourne. She is a Director of the National Centre for Research in Bushfire and Arson and a Director of Stanley and Co., consultants in sustainable policy. Janet specialises in social inclusion, transport, climate change and equity and bushfire arson. She has 80 refereed journal and book publications. 